\section{Advocacy: It's not a dirty word, it's a duty}

Advocacy: Public support for or recommendation of a particular cause or policy - Oxford English Dictionary

In a recent editorial, ${ }^{1}$ Louise Potvin outlined some of the ways in which public health is under attack in Canada today. Among other challenges, she noted:

"There is an intention of weakening Canadian public health when the individuals and organizations who are charged with looking after the health of Canada's population can no longer exercise their responsibility to advocate for... the highest interests of the population's health."

Advocacy is included as a core competency in Canada's recognized set of public health competencies ${ }^{2}$ and is also central to the ethical codes of medicine and nursing, two of the main parent disciplines of public health.

- The set of core competencies for public health in Canada defines advocacy as "speaking, writing or acting in favour of a particular cause, policy or group of people" and considers it to be one of "the competencies required to influence and work with others to improve the health and well-being of the public through the pursuit of a common goal." A public health practitioner is expected to be able to "Advocate for healthy public policies and services that promote and protect the health and well-being of individuals and communities."

- The Canadian Medical Association's Code of Ethics recognizes advocacy as a core activity of medicine: One of the ten fundamental responsibilities involves "advocating on behalf of the profession or the public."3

- The Canadian Nurses Association Code of Ethics considers advocating for change with respect to "how broad societal issues affect health and wellbeing" to be part of ethical practice. $^{4}$

Advocacy has always been an important part of public health practice, and it has always been unpopular, particularly with the private sector. In Renaissance Italy in the 14th and 15th centuries, the Boards of Health were criticized by the merchants, who complained that their economic well-being was disrupted by the Boards' regulation of trade and commerce; meanwhile, the Health Officers complained of the hostility of the merchants and the need to effect compromise between public well-being and economic necessity. ${ }^{5}$

Advocacy was also a vitally important tool in the 19th century, both in fighting the ills of industrialization and in proposing better, healthier ways to organize society. This tradition has continued throughout the 20th century, in fighting the many industries (tobacco, automobile, the chemical industry, mining, fast foods, alcohol and many others) whose activities may harm health.

Public health advocacy has also been important in opposing harmful government policies that support or fail to control such harmful economic activity as well as those that create or

\section{Le plaidoyer pour la santé* : ce n'est pas un gros mot, c'est un devoir}

Par définition, un plaidoyer est l'expression d'un soutien public à une cause ou à une opinion (Larousse)

Dans un récent éditorial, ${ }^{1}$ Louise Potvin décrivait certaines des attaques dont la santé publique fait l'objet au Canada aujourd'hui. Entre autres défis, elle notait :

"On cherche à affaiblir la santé publique canadienne lorsque les personnes et les organisations qui ont la charge de la santé de la population ne peuvent plus exercer leur mandat de plaidoyer et porter... les intérêts supérieurs de la santé de la population ".

Le plaidoyer pour la santé fait partie des compétences essentielles en santé publique reconnues au Canada; ${ }^{2}$ il est aussi au cœur des codes de déontologie de la médecine et des soins infirmiers, deux des grandes disciplines parentes de la santé publique.

- Les compétences essentielles en santé publique au Canada définissent le plaidoyer comme étant « le fait d'argumenter, d'écrire ou d'agir en faveur d'une cause, d'une politique ou d'un groupe de personnes " et en font l'une des « compétences requises permettant d'influencer et de mobiliser les partenaires dans l'atteinte d'un but commun soit l'amélioration de la santé et le bien-être de la population ». Un praticien de la santé publique devrait pouvoir «Plaider en faveur de politiques et de services de santé publique qui favorisent et protègent la santé à l'échelle individuelle et communautaire ».

- Le Code de déontologie de l'Association médicale canadienne reconnaît en l'action de plaidoyer une activité de base de la médecine et fait du " plaidoyer en faveur des intérêts de la profession ou du public ${ }^{3}$ » l'une de ses 10 responsabilités fondamentales.

- Le Code de déontologie de l'Association des infirmières et infirmiers du Canada considère que plaider pour le changement, dans la mesure où " les grandes questions sociales touchent la santé et le bien-être ", fait partie d'une pratique infirmière respectueuse de l'éthique. ${ }^{4}$

La fonction de plaidoyer a toujours été un élément important de la pratique en santé publique, et elle a toujours été impopulaire, surtout auprès du secteur privé. Dans l'Italie de la Renaissance aux $14^{\mathrm{e}}$ et $15^{\mathrm{e}}$ siècles, les conseils de santé étaient critiqués par les marchands, qui se plaignaient que leur bien-être économique était perturbé par la réglementation des échanges et du commerce exercée par ces conseils; quant aux agents de santé, ils se plaignaient de l'hostilité des marchands et du besoin de trouver un compromis entre le bien-être public et les impératifs économiques. ${ }^{5}$

Le plaidoyer a aussi été un outil d'une importance vitale au $19^{\mathrm{e}}$ siècle, à la fois pour combattre les méfaits de l'industrialisation et pour proposer de meilleurs moyens, plus sains, d'organiser la société. La tradition s'est perpétuée au $20^{\mathrm{e}}$ siècle par les luttes

*C'est par l'expression « plaidoyer » que le Centre de collaboration nationale traduit de l'anglais la fonction d' " advocacy ». http://www.ccnpps.ca/fr/ 
perpetuate social injustice and health inequity. Indeed, many of the public health heroes that CPHA lauded in its centenary ${ }^{6}$ and honours with its awards ${ }^{7}$ were or are prominent public health advocates.

In the past, society and governments not only understood the importance of advocacy and the need for public health to sometimes oppose powerful vested interests, they entrenched protection for the role of Medical Officers of Health $(\mathrm{MOH})$ in legislation. For example, Ontario's 1883 Public Health Act required a two-thirds vote of the Local Board of Health and the written permission of the Minister of Health before a $\mathrm{MOH}$ could be fired. One hundred years later, that protection was reconfirmed in section 66 of the new Health Protection and Promotion Act.

The need for such protection was dramatically evidenced in 2002 when Dr. David Swann, the MOH for Palliser Health Authority in Alberta, was fired for speaking out in support of the Kyoto Protocol and the importance for the health of the public of limiting greenhouse gas emissions. Fortunately, public pressure swiftly led to his reinstatement, but the fact this could happen is troubling.

Even more troubling, of course, is the 'war on science' that the current federal government is conducting, ${ }^{8}$ which precludes federal scientists, including scientists at the Public Health Agency of Canada, as well as the Chief Public Health Officer of Canada, from speaking out publicly on a range of topics that are political favourites of this government. The solid science on asbestos, safe injection sites, climate change, salt in our diet and a host of other issues is ignored and our public health advocates are muzzled.

Governments and corporations that act in ways that harm health and the environment understand that knowledge is power, and they are afraid of it. That is why - understanding also that power can limit and control knowledge - they use their power to limit the production and dissemination of knowledge that contradicts their ideological or economic interests.

Not surprisingly, public health advocacy is unpopular in some quarters, notably in governments and corporations but also, troublingly, among leaders in some health authorities. They see public health advocacy as inappropriate, even unprofessional, and they often want to avoid upsetting the Minister. In some cases, they have effectively silenced the $\mathrm{MOH}$ in favour of the CEO or - even worse - the 'official spokesperson', neither of whom can speak with the knowledge, expertise or authority of the $\mathrm{MOH}$

Moreover, governments and corporations have to some extent succeeded in imposing their view not only on public health professionals but on the academic community too. It is regrettable, to say the least, that some parts of the academy have come to accept the view that speaking out about the evidence and its implications is somehow a display of bias and is unprofessional and unscientific.

This form of self-censorship is deplorable; scientists do not check their citizenship at the lab door, they have as much right as anyone to speak out. Indeed, when it comes to speaking out on the societal and public policy implications of their research, who else is better placed to do so? contre de nombreuses industries (tabac, automobile, produits chimiques, exploitation minière, restauration rapide, alcool et bien d'autres) dont les activités peuvent nuire à la santé.

Le plaidoyer en santé publique joue également un rôle important en s'opposant aux politiques gouvernementales nocives qui soutiennent ou qui omettent de contrôler ces activités économiques nuisibles, ainsi que celles qui créent ou qui perpétuent l'injustice sociale et les iniquités en matière de santé. À n'en pas douter, bien des " héros de la santé publique " salués par l'ACSP lors de son centenaire ${ }^{6}$ et récompensés par ses prix $^{7}$ étaient ou sont toujours de grands défenseurs de la santé publique qui ont exercé cette fonction de plaidoyer.

Par le passé, non seulement la société et les gouvernements comprenaient-ils l'importance de la fonction de plaidoyer et la nécessité pour la santé publique de s'opposer parfois aux puissants intérêts en place, mais ils ont ancré dans la loi la protection du rôle du médecin hygiéniste ou du directeur de santé publique. Par exemple, pour pouvoir renvoyer un médecin hygiéniste en Ontario, la Loi sur la santé publique de 1883 exigeait que la décision soit prise par les deux tiers des membres du conseil de santé local et que le ministre de la Santé donne son consentement écrit. Une centaine d'années plus tard, cette protection a été réitérée à l'article 66 de la nouvelle Loi sur la protection et la promotion de la santé.

Le besoin d'une telle protection a été prouvé de façon spectaculaire en 2002 lorsque le Dr David Swann, médecin hygiéniste de l'autorité sanitaire de Palliser, en Alberta, a été congédié pour s'être prononcé en faveur du Protocole de Kyoto et de l'importance pour la santé du public de limiter les émissions de gaz à effet de serre. Heureusement, le tollé général qui s'est ensuivi a promptement mené à sa réintégration, mais le simple fait que cela ait pu se produire est troublant.

Encore plus troublante, bien sûre, est la "guerre à la science » que mène le gouvernement fédéral actuel, ${ }^{8}$ qui empêche les chercheurs fédéraux, notamment ceux de l'Agence de la santé publique du Canada, ainsi que l'administrateur en chef de la santé publique du Canada, de s'exprimer publiquement sur de nombreux sujets qui sont les marottes politiques de ce gouvernement. On élude ainsi des données scientifiques solides sur l'amiante, les sites d'injection supervisée, les changements climatiques, le sel dans notre alimentation et une foule d'autres questions, et on musèle ceux qui plaident en faveur de la santé publique.

Les gouvernements et les grandes entreprises dont les agissements nuisent à la santé et à l'environnement comprennent que savoir, c'est pouvoir; le savoir leur fait peur. C'est pourquoi - sachant aussi que le pouvoir peut limiter et contrôler le savoir - ils usent de leur pouvoir pour limiter la production et la diffusion des connaissances contraires à leur idéologie ou à leurs intérêts économiques.

Comme il fallait s'y attendre, la fonction de plaidoyer pour la santé est impopulaire dans certains milieux, notamment au sein de gouvernements et de grandes entreprises, mais aussi, ce qui est troublant, chez les dirigeants de certaines organisations régionales de santé. Ces derniers jugent que le plaidoyer pour la santé est inapproprié, et même non professionnel, et veulent souvent éviter de contrarier le ministre. Certains ont réduit leur directeur de santé publique au silence en laissant plutôt la parole au directeur général de l'organisme, ou pire encore à un « porte-parole officiel », 
But speaking out is more than a right, it is in fact a duty, especially for Medical Officers of Health and tenured academics. They have privileges in terms of job security and income that bring with them duties and responsibilities. We grant tenure to academics in the name of academic freedom, but what is that but the freedom also to speak out - and not just the freedom to speak out, but surely an obligation to do so. Why else would we grant the extraordinary privilege that is tenure - a job for life. Great privilege brings great obligations.

The effect of the combination of political and corporate opposition to public health advocacy has been to at least partially shut down public health advocates across this country. This situation is not only a denial of an essential public health competency, it is also a major dis-service to the public interest. It has to be stopped, and this means that public health professionals and academics - and the professional organizations that represent them - have to stand up and speak out in favour of their right to stand up and speak out. Advocacy for the health of the public is our duty, it is an ethical obligation and a sacred trust.

\section{Trevor Hancock \\ Senior Editor, CJPH}

doi: 10.17269/CJPH.106.5094

\section{REFERENCES}

1. Potvin L. Canadian public health under siege. Can J Public Health 2014;105(6): e401-3. PMID: 25560884.

2. Public Health Agency of Canada. Core Competencies for Public Health in Canada (Release 1.0). Ottawa, ON: PHAC, 2008.

3. Canadian Medical Association. CMA Code of Ethics. Ottawa: CMA, 2004.

4. Canadian Nurses Association. Code of Ethics for Registered Nurses. Ottawa: CNA, 2008.

5. Cipolla C. Public Health and the Medical Profession in the Renaissance. Cambridge: Cambridge University Press, 1976

6. Canadian Public Health Association. This is Public Health: A Canadian History. Ottawa: CPHA, 2010. Available as an interactive e-book at: http://www.cpha. ca/en/programs/history/book.aspx (Accessed March 31, 2015).

7. CPHA - Past Award Recipients. Available at: http://www.cpha.ca/en/about/ awards/past.aspx (Accessed March 31, 2015).

8. Turner C The War on Science: Muzzled Scientists and Wilful Blindness in Stephen Harper's Canada. Vancouver, BC: Greystone Books, 2013. ni l'un ni l'autre n'ayant les connaissances, le savoir-faire ou l'autorité d'un médecin spécialiste, directeur de santé publique.

De plus, les gouvernements et les grandes entreprises réussissent dans une certaine mesure à imposer leur point de vue non seulement aux professionnels de la santé publique, mais aussi aux enseignants. Il est pour le moins regrettable que certains universitaires en soient venus à accepter l'opinion que de se prononcer sur les données probantes et leurs conséquences soit la démonstration d'un parti pris, et donc une conduite non professionnelle et non scientifique.

Cette forme d'autocensure est déplorable; les chercheurs ne laissent pas leur citoyenneté à la porte du laboratoire : ils ont comme tout le monde le droit de s'exprimer. À vrai dire, quand il s'agit de parler des répercussions de leurs recherches sur le plan sociétal et sur celui des politiques publiques, qui est mieux placé qu'eux pour le faire?

Mais parler et plaider en faveur de la santé est plus qu'un droit, c'est un devoir, surtout pour les directeurs de santé publique ou les médecins spécialistes en santé publique et les professeurs permanents. Les privilèges dont jouissent ces personnes en matière de sécurité d'emploi et de revenu s'accompagnent de devoirs et de responsabilités. Nous accordons la permanence aux universitaires au nom de la liberté d'enseignement, mais n'est-ce pas là un autre nom pour la liberté d'expression? Et non pas simplement la liberté, mais l'obligation d'expression. Pour quelle autre raison accorderions-nous le privilège extraordinaire qu'est la permanence - un emploi à vie? Un si grand privilège vient avec de grandes obligations.

L'effet combiné de l'opposition politique et économique à la fonction de plaidoyer en santé publique a été de faire taire, au moins en partie, les défenseurs de la santé publique dans tout le pays. Une telle situation est non seulement une négation d'une compétence essentielle en santé publique, c'est aussi rendre un très mauvais service à l'intérêt général. Il faut que cela cesse, et pour cela, que les professionnels de la santé publique et les universitaires ainsi que les associations professionnelles qui les représentent prennent position et s'expriment en faveur de leur droit de prendre position et de s'exprimer. Nous avons le devoir de plaider en faveur de la santé du public; c'est une obligation éthique et un principe sacré.

\section{Trevor Hancock \\ Rédacteur de la RCSP}

doi: $10.17269 / \mathrm{CJPH} .106 .5094$

\section{RÉFÉRENCES BIBLIOGRAPHIQUES}

1. Potvin L. "La santé publique canadienne en état de siège ", Rev can santé publique 2014;105(6):e401-403. PMID: 25560884.

2. Agence de la santé publique du Canada. Compétences essentielles en santé publique au Canada (version 1.0). Ottawa, ON: l'Agence, 2008.

3. Association médicale canadienne. Code de déontologie de l'AMC. Ottawa: l'AMC, 2004.

4. Association des infirmières et infirmiers du Canada. Code de déontologie des infirmières et infirmiers. Ottawa: 1'AIIC, 2008.

5. Cipolla C. Public Health and the Medical Profession in the Renaissance. Cambridge: Cambridge University Press, 1976.

6. Association canadienne de santé publique. La santé publique : une histoire canadienne. Ottawa: l'ACSP, 2010. Disponible en livre électronique interactif sur : http://www.cpha.ca/fr/programs/history/book.aspx (consulté le 31 mars 2015).

7. ACSP - Anciens lauréats et lauréates. Sur Internet : http://www.cpha.ca/fr/ about/awards/past.aspx (consulté le 31 mars 2015).

8. Turner C. The War on Science: Muzzled Scientists and Wilful Blindness in Stephen Harper's Canada. Vancouver: Greystone Books, 2013. 